\title{
KONTRIBUSI KOMODITAS PERTANIAN TERHADAP INFLASI DI KOTA MANADO TAHUN 2019
}

\author{
Angelita Monica Leiley \\ Jean Fanny Junita Timban \\ Olly Esry Haryani Laoh
}

Naskah diterima melalui Email agrisosioekonomi@unsrat.ac.id

Sabtu, 1 Agustus 2020

Disetujui diterbitkan

Senin, 21 September 2020

\begin{abstract}
This study aims to determine the effect of agricultural commodities on inflation in the city of Manado and what agricultural commodities have a significant effect on inflation in the city of Manado. This research was conducted in December 2019 until February 2020. Data collection was obtained through secondary data obtained from the Central Statistics Agency of North Sulawesi Province which was taken through the official website of BPS North Sulawesi Province. Sampling uses a time series data source. Data analysis uses multiple linear regression analysis methods. This analysis will produce a pattern and closeness of the relationship between the dependent variable and the independent variable, estimate the effect of the independent variable on inflation in the city of Manado, and be able to predict inflation in the city of Manado if the magnitude of the independent variable is known. The results showed that the Manado City Inflation was influenced by agricultural commodities, namely vegetables, legume inflation, fruit inflation and seasoning inflation. Grain groups have no effect on inflation in the City of Manado. ${ }^{*}$ eprm*
\end{abstract}

Keywords: inflation, agricultural commodities, Manado City

\begin{abstract}
ABSTRAK
Penelitian ini bertujuan untuk mengetahui pengaruh komoditas pertanian terhadap inflasi di Kota Manado dan komoditas pertanian apa saja yang berpengaruh signifikan terhadap inflasi di Kota Manado. Penelitian ini dilaksanakan pada bulan Desember 2019 sampai Februari 2020. Pengumpulan data diperoleh melalui data sekunder yang diperoleh dari Badan Pusat Statistik Provinsi Sulawesi Utara yang diambil melalui website resmi BPS Provinsi Sulawesi Utara. Penggambilan sampel menggunakan sumber data sekunder untaian waktu (time series). Analisis data menggunakan metode analisis regresi linear berganda. Analisis ini akan menghasilkan pola dan keeratan hubungan antara variabel dependen dan variabel independen, mengestimasi pengaruh variabel independen terhadap inflasi di Kota Manado, dan mampu memprediksi inflasi di Kota Manado apabila besarnya variabel independen diketahui. Hasil penelitian menunjukkan bahwa inflasi di Kota Manado dipengaruhi oleh komoditas pertanian yaitu kelompok sayur-sayuran, inflasi kacang-kacangan, inflasi buah-buahan dan inflasi bumbu-bumbuan. Kelompok padi-padian tidak berpengaruh pada inflasi Kota Manado. ${ }^{*}$ eprm*
\end{abstract}

Kata kunci : inflasi, komoditas pertanian, Kota Manado

Agrisosioekonomi: 


\section{PENDAHULUAN}

\section{Latar Belakang}

Komoditas pertanian sangat penting dan strategis karena menyangkut kebutuhan dasar manusia. Teori Piramida Maslow menyatakan bahwa kebutuhan fisiologis manusia termasuk pangan merupakan kebutuhan paling mendasar yang harus dipenuhi. Seiring dengan terus meningkatnya jumlah populasi di dunia yang tidak diimbangi dengan kenaikan penyediaan bahan pangan karena produktifitas pertanian yang meningkat lebih lambat mengakibatkan ketahanan pangan global berada dalam kondisi yang mengkhawatirkan. Kondisi ini menyebabkan harga komoditas pertanian di dunia terus meningkat (Sujai, 2011). Dampak terbesar akibat kenaikan harga pangan ini adalah meningkatnya inflasi sehingga memberatkan masyarakat di Indonesia terutama masyarakat miskin.

Inflasi (inflation), yaitu kenaikan tingkat harga yang terjadi terus-menerus, mempengaruhi indivu, pengusaha, dan pemerintah. Inflasi secara umum dianggap sebagai masalah penting yang harus diselesaikan dan menjadi agenda utama politik dan pengambilan kebijakan. Meningkatnya harga yang tercemin melalui angka inflasi secara umum disebabkan oleh meningkatnya permintaan, menurunnya penawaran, serta ekspektasi masyarakat terhadap perubahan harga pada masa yang akan datang.

Secara historis, tingkat dan volatitas inflasi Indonesia lebih tinggi dibanding dengan Negaranegara berkembang lain. Sementara Negaranegara berkembang lain mengalami tingkat inflasi di antara 3-5 persen per tahun pada periode 2005-2014, Indonesia memiliki rata-rata tingkat inflasi tahunan sekitar 8,5 persen dalam periode yang sama. Baru mulai dari tahun 2015 inflasi di Indonesia boleh dikatakan terkendali.

Sepanjang tahun 2019 di Kota Manado mengalami inflasi sebanyak lima kali dan deflasi sebanyak tujuh kali dan menjadi penyumbang inflasi terbesar di Indonesia pada bulan November 2019. Kelompok pengeluaran bahan makanan merupakan salah satu penyumbang andil terbesar terjadinya inflasi kota Manado karena sub kelompok bahan makanan terdiri dari komoditas Pertanian.
Adanya fluktuasi harga bahan makanan yang tajam pada bulan-bulan tertentu sepanjang tahun 2019 mengakibatkan suatu kondisi yang tidak normal dalam suatu kegiatan perekonomian Kota Manado dimana komoditas pertanian menjadi salah satu komponen penyumbang Inflasi Manado. Hal ini menjadi menarik untuk diteliti berkaitan dengan berapa besar pengaruh komoditas pertanian terhadap inflasi di Kota Manado.

\section{Rumusan Masalah}

Perumusan masalah dalam penelitian ini adalah berapa besar atau pengaruh komoditas pertanian terhadap inflasi di Kota Manado?

\section{Tujuan Penelitian}

Tujuan dalam penelitian ini adalah untuk melihat bagaimana pengaruh komoditas pertanian terhadap inflasi di Kota Manado dan Komoditas pertanian apa saja yang berpengaruh signifikan terhadap inflasi di Kota Manado.

\section{Manfaat Penelitian}

1. Selain untuk penyelesaian studi akhir, juga dapat menambahkan pemahaman dan pengetahuan kepada penulis tentang bagaimana menganalisis kontribusi komoditas pertanian terhadap inflasi di Kota Manado.

2. Sebagai bahan informasi bagi pelaku ekonomi khususnya di bidang ekonomi pertanian tentang kontribusi komoditi pertanian terhadap inflasi di Kota Manado.

\section{METODE PENELITIAN}

\section{Waktu dan Tempat Penelitian}

Penelitian berlangsung selama 3 bulan yaitu sejak bulan Desember 2019 sampai Februari 2020, dari persiapan sampai penyusunan laporan hasil penelitian. Penelitian dilaksanakan di Kota Manado Provinsi Sulawesi Utara.

\section{Metode Pengumpulan Data}

Metode pengumpulan data dalam penelitian ini menggunakan data sekunder yang diperoleh dari Badan Pusat Statistik Provinsi Sulawesi Utara yang diambil melalui website resmi BPS Provinsi Sulawesi Utara. 


\section{Metode Pengumpulan Sampel}

Penelitian menggunakan sumber data sekunder untaian waktu (time series) inflasi Kota Manado Januari - Desember 2019 yang didapat dari katalog tahunan Badan Pusat Statistik Sulawesi Utara.

\section{Konsep Pengukuran Variabel}

Variabel-variabel yang di ukur dalam penelitian ini terdiri dari :

1. Variabel tak bebas berupa data Inflasi kota Manado bulan Januari - Desember 2019.

2. Variabel bebas diambil dari salah satu kelompok pengeluaran untuk mengukur inflasi Kota Manado yaitu data inflasi komoditas bahan makanan yang terdiri dari Sub kelompok berupa Padi-padian dan Umbi-umbian, Sayursayuran, Kacang-kacangan, Buah-buahan, dan Bumbu-bumbuan.

\section{Metode Analisis Data}

Berdasarkan tujuan penelitian untuk mengetahui bagaimana kontribusi antara variabel independen dengan variabel dependen yaitu Inflasi, maka teknik statistik yang tepat adalah Analisis Regresi Linear Berganda. Analisis ini akan menghasilkan pola dan keeratan hubungan antara variabel dependen dan variabel independen, mengestimasi pengaruh variabel independen terhadap inflasi di kota Manado, dan mampu memprediksi inflasi di Kota Manado apabila besarnya variabel independen diketahui. Peneilitian dilakukan menggunaka program SPSS 19.

\section{Regresi Linear berganda}

Model analisis regresi yang digunakan

$\mathrm{Y}=\mathrm{b} 0+\mathrm{b} 1 \mathrm{X} 1+\mathrm{b} 2 \mathrm{X} 2+\mathrm{b} 3 \mathrm{X} 3+\mathrm{b} 4 \mathrm{X} 4+\mathrm{b} 5 \mathrm{X} 5+\mathrm{Ui}$

Dimana :

$\mathrm{Y}=$ Inflasi Manado

b0 $=$ Konstanta

b1 $=$ koefisien regresi inflasi padi-padian

b2 = koefisien regresi inflasi sayur-sayuran

b3 = koefisien regresi inflasi kacang-kacangan

b4 = koefisien regresi inflasi buah-buahan

b5 = koefisien regresi inflasi bumbu-bumbuan

$\mathrm{X} 1=$ Inflasi padi-padian

$\mathrm{X} 2$ = Inflasi sayur-sayuran

$\mathrm{X} 3$ = Inflasi kacang-kacangan

$\mathrm{X} 4$ = Inflasi buah-buahan

$\mathrm{X} 5$ = Inflasi bumbu-bumbuan

$\mathrm{Ui}=$ Error

\section{Uji Asumsi - Asumsi Regresi}

1. Uji Normalitas

Uji normalitas dimaksudkan untuk mengetahui apakah dalam variabel yang diteliti data terdistribusi normal atau tidak. Hal ini berarti bahwa uji normalitas diperlukan untuk menjawab pertanyaan apakah syarat sampel yang representatif terpenuhi atau tidak, sehingga hasil penelitian dapat digeneralisasi pada populasi (Nahrowi dan Usman, 2009).

\section{Uji Multikolinearitas}

Uji multikolinearitas adalah untuk melihat ada atau tidaknya korelasi yang tinggi antara variabel-variabel bebas dalam suatu model regresi linear berganda. Jika ada korelasi yang tinggi di antara variabel-variabel bebasnya, maka hubungan antara variabel bebas terhadap variabel terikatnya menjadi terganggu. Alat statistik yang sering digunakan untuk menguji gangguan multikolinearitas adalah dengan Variance Inflation Factor (VIF) dan nilai Tollerance (TOL). Dikatakan No Multikolinearitas (asumsi terpenuhi) jika nilai VIF $<10$ atau nilai TOL $>0,1$.

\section{Uji Heteroskedastisitas}

Heteroskedastisitas merupakan kondisi dimana terjadinya ketidaksamaan varian dari residual pada model regresi. Plot residual yang ideal adalah plot yang menggambarkan titik-titik menyebar di sekitar nol dengan penyimpangan tidak terlalu besar dari nol dan tidak memberikan suatu kecenderunagn pola tertentu.

4. Uji Autokorelasi

Autokorelasi digunakan untuk melihat apakah ada korelasi antara variabel itu sendiri yang berbeda waktu (data time series). Autokorelasi perlu dilakukan apabila data yang dianalisis merupakan data time series. Salah satu deteksi autokorelasi adalah uji durbin Watson dan run test.

\section{Uji Statistik}

1. Uji Koefisien Determinasi (R2)

Uji Koefisien Determinasi (R2) adalah besaran untuk melihat sejauh mana variabel terikat dapat diterangkan oleh variabel bebas. Nilainya berkisar antara nol dan satu, jika nilai koefisien determinasi semakin mendekati satu berarti semakin besar keragaman variabel bebas (Nahrowi dan Usman, 2009). Bentuk uji hipotesis yang digunakan adalah : 
2. Uji Koefisien Regresi Secara Serentak (Uji F)

Uji ini dilakukan untuk mengetahui apakah variabel bebas secara bersamasama/ serentak berpengaruh signifikan terhadap variabel tak bebas.

3. Uji Koefisien Regresi Secara Parsial (Uji t)

Uji ini dilakukan untuk mengetahui apakah masing-masing variabel bebas berpengaruh signifikan terhadap variabel tak bebas

\section{HASIL DAN PEMBAHASAN}

\section{Deskripsi Wilayah Penelitian}

Kota manado terletak di ujung utara pulau Sulawesi, pada posisi geografis $124^{\circ} 40^{\prime}-124^{\circ} 50^{\prime}$ BT dan $1^{\circ} 30^{\prime}-1^{\circ} 40^{\prime}$ LU dengan batas wilayah yaitu berbatasan dengan Kabupaten Minahasa Utara di sebelah utara, sebelah selatan dengan Kabupaten Minahasa, sebelah timur dengan Kabupaten Minahasa Utara dan Kabupaten Minahasa dan sebelah barat dengan Laut Sulawesi. Kota Manado terdiri dari 11 kecamatan dan 87 kelurahan dengan luas wilayah sebesar 162,53 km2 dan jumlah penduduk sebanyak 431.880 pada tahun 2018 menurut BPS. Iklim di kota ini adalah iklim tropis dengan suhu rata-rata $24^{\circ}-27^{\circ} \mathrm{C}$. curah hujan rata-rata $3,187 \mathrm{~mm} /$ tahun dengan iklim terkering di sekitar bulan Agustus dan terbasah pada bulan januari. Intensitas penyinaran matahari rata-rata $53 \%$ dan kelembaban $\pm 84 \%$. (BPS. 2020).

\section{Perkembangan Inflasi \\ Kota Manado Tahun 2019}

Secara umum sepanjang tahun 2019 di Kota Manado tercatat mengalami inflasi sebanyak lima kali dan deflasi sebanyak tujuh kali. Inflasi tercatat pada bulan Januari, Mei-Juni dan Oktober-November. Inflasi tertinggi tercatat pada bulan Juni 2019 sebesar 3,60 persen dan tertinggi se-Indonesia pada bulan November 2019 sebesar 3,30 persen. Inflasi yang relatif tinggi pada bulan Juni dan November diduga karena pengaruh cuaca akibat musim hujan yang diduga mempengaruhi produksi dan distribusi barang/jasa mendorong terjadinya kenaikan harga beberapa komoditas bahan makanan seperti tomat sayur, cabai rawit, pisang dan bawang merah. Pergerakkan inflasi tahun dasar 2018 kota Manado 2019 dapat dilihat pada gambar 1.

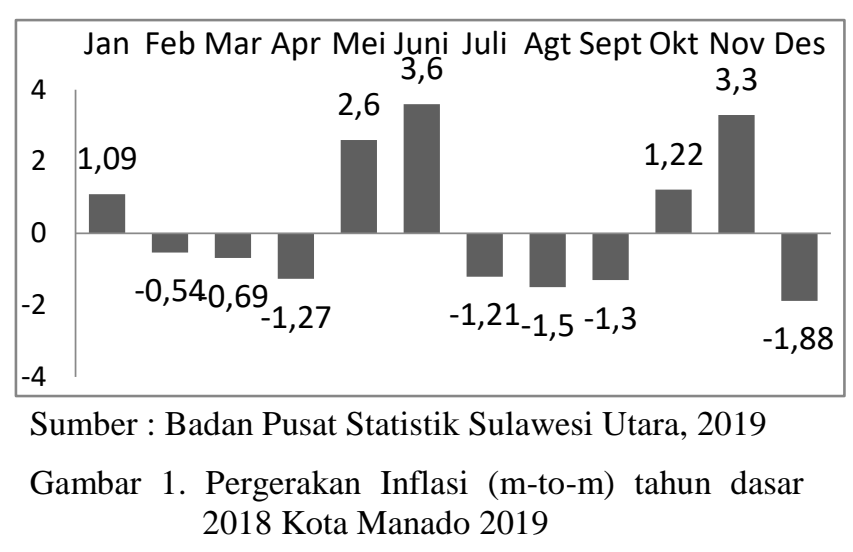

Selain itu, pengaruh perayaan Idul Fitri juga diduga turut berpengaruh terhadap kenaikan harga. Pengaruh itu mungkin disebabkan adanya pola perubahan konsumsi masyarakat terhadap beberapa komoditas tertentu yang pada akhirnya berpengaruh pada permintaan komoditas tersebut. Komoditas pertanian memberikan andil yang besar dalam pergerakan Inflasi Kota Manado tahun 2019 karena komoditas tomat sayur menjadi komoditas dengan andil Inflasi terbesar tahun 2019 diikuti dengan komoditas pisang dan cabai rawit. Komoditas penyumbang andil inflasi tahun 2019 dapat dilihat pada gambar 2.

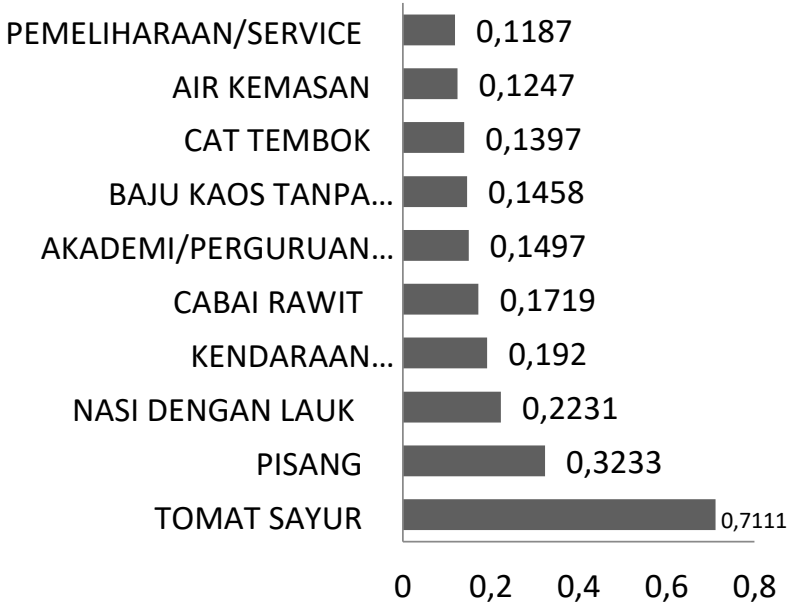

Sumber : Badan Pusat Statistik Sulawesi Utara, 2019

Gambar 2. Komoditas Penyumbang Andil Inflasi Tahun 2019

Selama periode lima tahun terkhir, inflasi kota Manado paling tinggi tercatat pada tahun 2015 yaitu sebesar 5,56 sedangkan inflasi terendah tercatat pada tahun 2016 hanya 0,35 persen. Jika dibandingkan dengan inflasi nasional, pada tahun 2016 dan 2017 inflasi Kota Manado lebih rendah daripada inflasi nasional, sedangkan tahun 2015, 
2018 dan 2019 inflasi Kota Manado lebih tinggi daripada inflasi nasional. Pada tahun 2019, inflasi nasional tecatat 2,72 persen. Nilai ini tercatat rendah dibanding capaian inflasi Kota Manado sebesar 3,52 persen. (BPS, 2020). Perbandingan inflasi Kota Manado dan Nasional dapat dilihat pada gambar 3 .

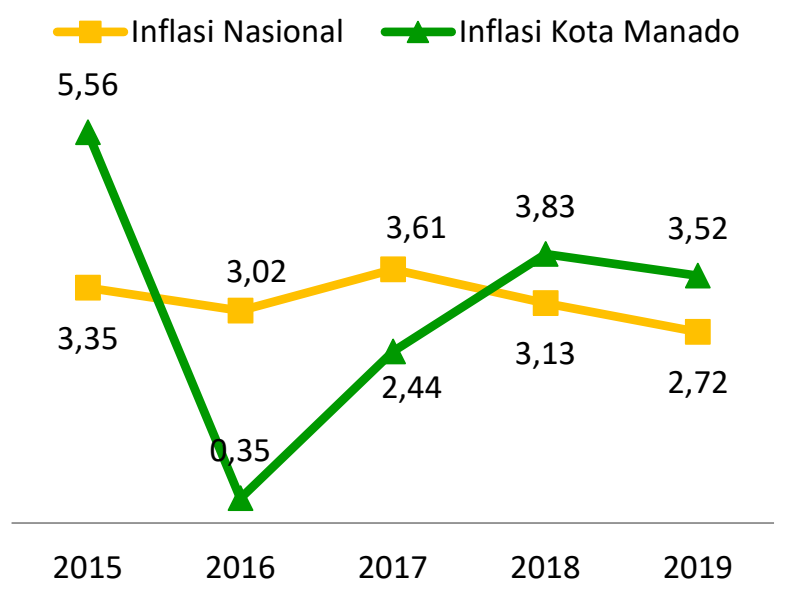

Sumber : Badan Pusat Statistik Sulawesi Utara, 2019

Gambar 3. Perbandingan inflasi (y-on-y) Kota Manado dan nasional Tahun 2015-2019

\section{Persentase Pergerakan Inflasi Komoditas Pertanian Januari 2019}

Kota Manado mengalami inflasi sebesar 1,09 persen dengan IHK sebesar 135,09 persen pada bulan Januari 2019. Terjadi peningkatan indeks pada kelompok bahan makanan sebesar 3,47 persen. Kelompok bahan makanan yang mencakup komoditas pertanian juga terdiri atas Dari sub kelompok tersebut kemudian diuraikan komoditas yang memberikan andil terbesar di Kota Manado bulan Januari 2019 yaitu Tomat sayur sebesar 0,3308 persen, bawang merah sebesar 0,1552 persen, pisang sebesar 0,0849 persen, biji nangka/kuniran sebesar 0,0589 persen, semangka sebesar 0,0239, anggur sebesar 0,0191 persen, kopi bubuk sebesar 0,0060 persen dan sari jeruk sebesar 0,0035 persen. Sedangkan penyumbang deflasi adalah cabai rawit sebesar 0,2563 persen daun bawang sebesar 0,0806 persen, papaya sebesar 0,0358 persen, cabai merah sebesar 0,0273 persen, kangkung sebesar 0,0271 persen, bawang putih sebesar 0,0131 persen, selada/daun selada sebesar 0,0109, sawi hijau sebesar 0,0099 persen, jagung manis sebesar 0,0065 persen.

\section{Pergerakan Inflasi Komoditas Pertanian Februari 2019}

Bulan Februari 2019 Kota Manado mengalami deflasi sebesar 0,54 persen dimana bahan makanan mengalami penurunan indeks sebesar 1,85 persen dan menjadi kelompok tertinggi yang mengalami penurunan indeks harga. Komoditas dengan penyumbang deflasi terbesar yaitu Tomat sayur sebesar 0,1938 bawang merah sebesar 0,0736 persen, pepaya sebesar 0,0707 persen, jeruk nipis/limau sebesar 0,0644 persen dan daun bawang sebesar 0,061 persen. Sedangkan penyumbang inflasi terbesar yaitu Pisang sebesar 0,0722 persen anggur sebesar 0,0319 persen, cabai rawit sebesar 0,0192 persen, kangkung sebesar 0,0177 persen, kembang kol sebesar 0,0127, buncis sebesar 0,0094 persen.

\section{Persentase Pergerakan Inflasi Komoditas Pertanian Maret 2019}

Kota Manado pada bulan Maret 2019 mengalami deflasi sebesar 0,69 persen yang sebagian besar disebabkan oleh kelompok bahan makanan. Deflasi disebabkan karena adanya penurunan indeks harga pada bahan makanan sebesar 3,85 persen. Sama seperti bulan februari, komoditas penyumbang deflasi terbesar yaitu tomat sayur sebesar 0,6144 persen diikuti dengan daun bawang sebesar 0,0802 persen, bawang merah sebesar 0,0432 persen, biji nangka/kuniran sebesar 0,0246 persen, wortel sebesar 0,0166 persen, selada/daun selada sebesar 0,0154 persen, persen dan komoditas penyumbang inflasi terbesar yaitu cabai rawit sebesar sebesar 0,1817 persen, bawang putih sebesar 0,0458 persen, jeruk nipis/limau sebesar 0,0259 persen, pisang sebesar 0,0156 persen, margarine sebesar 0,0027 persen, pepaya sebesar 0,0019 persen dan kelapa sebesar 0,0019 persen.

\section{Persentase Pergerakan Inflasi Komoditas Pertanian April 2019}

Bulan April 2019 kota Manado mengalami deflasi sebesar 1,27 persen atau penurunan indeks harga dari 158,03 di bulan Maret 2019 menjadi 147,81 pada April 2019. Komoditas yang memberikan sumbangan deflasi antara lain: tomat sayur sebesar 1,3188 persen, beras sebesar 0,0692 persen, daun bawang sebesar 0,0522 persen; kangkung sebesar sebesar 0,0344 persen; kembang 
kol sebesar 0,0294; buncis sebesar 0,0168 persen; dan terong panjang sebesar 0,0155 persen sedangkan komoditas yang memberikan sumbangan inflasi antara lain: bawang merah sebesar 0,1630 persen, bawang putih sebesar 0,1440 persen, anggur sebesar 0,0430 persen, cabai merah sebesar 0,0231 persen, cabai rawit sebesar 0,0067 persen, jagung manis sebesar 0,0060 .

\section{Persentase Pergerakan Inflasi Komoditas Pertanian Mei 2019}

Kota Manado pada bulan Mei 2019 mengalami Inflasi sebesar 2,60 persen atau terjadi peningkatan indeks sebesar 166,85 persen. Komoditas pertanian yang memberikan sumbangan inflasi antara lain tomat sayur sebesar 2,13 persen, cabai rawit sebesar 0,3847 persen, pepaya sebesar 0,0791 persen, bawang putih sebesar sebesar 0,0631 persen, kangkung sebesar 0,0454 , bawang merah sebesar 0,0317 persen dan cabai merah sebesar 0,0301 persen. Sedangkan komoditas yang memberikan sumbangan deflasi antara lain: beras sebesar 0,1394 persen, lemon sebesar 0,0188 persen, jeruk nipis/limau sebesar 0,0088 persen, pisang sebesar 0,0062 persen, kol putih/kubis sebesar 0,0037 persen, sawi hijau sebesar 0,0033, jagung manis sebesar 0,0026 persen, dan wortel sebesar 0,0014 persen.

\section{Persentase Pergerakan Inflasi Komoditas Pertanian Juni 2019}

Inflasi tertinggi Kota Manado terjadi pada bulan Juni yaitu sebesar 3,6 persen dimana kelompok bahan makanan naik sebesar 13,73 persen. Peningkatan indeks bahan makanan komoditas pertanian umumnya Komoditas pertanian yang memberikan sumbangan inflasi antara lain: tomat sayur sebesar 3,4514 persen, jeruk nipis/limau sebesar 0,0836 persen, lemon sebesar 0,0291 persen, bawang merah sebesar 0,028 persen, biji nangka/kuniran sebesar 0,0276 persen, cabai merah sebesar sebesar 0,0246 persen, semangka sebesar 0,023 dan kembang kol sebesar 0,0188 persen. Sedangkan komoditas pertanian yang memberikan sumbangan deflasi yaitu cabai rawit sebesar 0,3128 persen, bawang putih sebesar 0,106 persen, anggur sebesar 0,0407 persen, kangkung sebesar 0,0186, jagung manis sebesar 0,0085 persen, dan daun gedi sebesar 0,0046 persen.

\section{Persentase Pergerakan Inflasi Komoditas Pertanian Juli 2019}

Kota Manado pada bulan Juli 2019 mengalami Deflasi sebesar 1,21 persen dengan kelompok bahan makanan mengalami penurunan indeks sebesar 6,30 persen. Komoditas bahan makanan yang menyumbang deflasi yaitu tomat sayur sebesar 1,6258 persen, cabai rawit sebesar 0,1441 persen, bawang merah sebesar 0,1259 persen, lemon sebesar 0,0886 persen, jeruk nipis/limau sebesar 0,0331 persen, daun bawang sebesar 0,0177, cabai merah sebesar 0,0149 persen, bawang putih sebesar 0,0093 persen. Sedangkan komoditas yang memberikan sumbangan inflasi antara lain: beras sebesar 0,1971 persen, biji nangka/kuniran sebesar 0,0235 persen, wortel sebesar 0,017 persen dan kembang kol sebesar 0,0139 persen.

\section{Persentase Pergerakan Inflasi Komoditas Pertanian Agustus 2019}

Bulan Agustus 2019 Kota Manado mengalami deflasi sebesar 1,50 persen yaitu terjadi penururnan indeks pada kelompok bahan makanan sebesar 9,34 persen. Komoditas pertanian yang memberikan andil dalam deflasi Kota Manado Agustus 2019 berupa tomat sayur sebesar 3,0202 persen, bawang merah sebesar 0,1395 persen, kembang kol sebesar 0,0268 persen, daun bawang sebesar 0,0262 persen, bawang putih sebesar 0,0218 persen, sawi hijau sebesar sebesar 0,0159 persen, buncis sebesar 0,0151, pepaya sebesar 0,0115 persen. Sedangkan komoditas penyumbang inflasi yaitu cabai rawit sebesar 0,3049 persen, biji nangka/kuniran sebesar 0,0874 persen, pisang sebesar 0,0733 persen, apel sebesar 0,064 persen wortel sebesar 0,015 persen.

\section{Persentase Pergerakan Inflasi Komoditas Pertanian September 2019}

Kota Manado pada September 2019 mengalami deflasi sebesar 1,03 persen dimana bahan makanan mengalami deflasi sebesar 4,27 persen. Komoditas pertanian yang memberikan sumbangan deflasi antara lain: tomat sayur sebesar 1,0223 persen, bawang merah sebesar 0,1151 persen, biji nangka/kuniran sebesar 0,0351 persen, anggur sebesar 0,0281, bawang putih sebesar 0,0147. Sedangkan komoditas pertanian yang memberikan sumbangan inflasi yaitu cabai rawit sebesar 0,1377 persen, lemon 
sebesar 0,039 persen, buncis sebesar 0,0228 persen, daun bawang sebesar 0,019 persen, jeruk sebesar 0,0132 persen, sawi hijau sebesar 0,0125 persen, pisang sebesar 0,0107 , jeruk nipis/limau sebesar 0,0106 persen, daun paku/pakis sebesar 0,0092 persen.

\section{Persentase Pergerakan Inflasi Komoditas Pertanian Oktober 2019}

Kota Manado kembali mengalami inflasi pada bulan Oktober sebesar 1,22 persen dengan kelompok bahan makanan sebesar 5,13 persen. Komoditas pertanian sebagian besar memberikan sumbangan inflasi antara lain tomat sayur sebesar 0,8575 persen, cabai rawit sebesar 0,4278 persen, daun bawang sebesar 0,0822 persen, pisang sebesar 0,0747 persen, lemon sebesar 0,0710 persen, cabai merah sebesar 0,0534 persen, buncis sebesar sebesar 0,0373 persen, kangkung sebesar 0,0197, sawi hijau sebesar 0,0184 persen. Komoditas pertanian yamg menyumbang deflasi yaitu biji nangka/kuniran sebesar 0,0936 persen, bawang merah sebesar 0,0197 persen.

\section{Persentase Pergerakan Inflasi Komoditas Pertanian November 2019}

Kota Manado pada bulan November 2019 mengalami Inflasi sebesar 3,30 persen dimana terjadi peningkatan indeks pada kelompok bahan makanan 13,61 persen. Komoditas pertanian yang memberikan andil dalam inflasi bulan November 2019 antara lain tomat sayur sebesar 3,4102 persen, lemon sebesar 0,1117 persen, bawang merah sebesar 0,0673, jeruk nipis/limau sebesar 0,0595 persen, bunga papaya sebesar 0,0247 persen, jagung manis sebesar 0,0172 persen, jahe sebesar 0,0136 persen, nanas sebesar sebesar 0,0060 persen, sawi putih sebesar 0,0036 persen. Sedangkan komoditas penyumbang deflasi yaitu cabai rawit sebesar 0,0695 persen, papaya sebesar 0,0641 persen, buncis sebesar 0,0300 persen, kembang kol sebesar 0,0081 persen, ketimun sebesar 0,0121 persen, tauge/kecambah sebesar 0,0085 persen, bayam sebesar 0,0100 persen dan cabai merah sebesar 0,0197 .

\section{Persentase Pergerakan Inflasi Komoditas Pertanian Desember 2019}

Bulan Desember 2019 Kota Manado mengalami deflasi sebesar 1,88 persen yang salah satunya disebabkan oleh penurunan indeks kelompok bahan makanan sebesar 8,28 persen.
Komoditas pertanian yang memberikan sumbangan terhadap deflasi Desember 2019 yaitu tomat sayur sebesar 1,4749 persen; cabai rawit sebesar 0,4825 persen; lemon sebesar 0,1006 ; cabai merah sebesar 0,0667 persen; pepaya sebesar 0,0654 persen; daun bawang sebesar 0,0388 persen; jeruk nipis/limau sebesar 0,0370 persen, semangka sebesar 0,0266 persen; buncis sebesar 0,0248 persen, sari jeruk sebesar 0,0026 persen. Komoditas yang memberikan andil inflasi yaitu bawang merah sebesar 0,1140 persen; pisang sebesar 0,0351 persen; minyak goreng sebesar 0,0207 persen; biji nangka/ kuniran sebesar 0,0135 persen; daun paku/pakis sebesar 0,0080 dan jagung manis sebesar 0,0076 persen.

\section{Analisis Model Regresi}

Pengaruh kenaikan harga komoditas pertanian terhadap inflasi di kota Manado menggunakan analisis regeresi berganda dan data diolah menggunakan SPSS 19. Sesuai hasil olah data yang terdapat dalam Tabel Koefisien Uji t diperoleh persamaan sebagai berikut : $\mathrm{Y}=-0.289-0.060 \mathrm{X} 1+0.052 \mathrm{X} 2-0.354 \mathrm{X} 3+$ $0.068 \mathrm{X} 4-0.027 \mathrm{X} 5$

Hasil uji statistic diperoleh nilai R2 sebesar 98,9 persen; yang mengartikan bahwa variasi naik turunnya variabel Y (inflasi Kota Manado) dapat dijelaskan oleh variasi naik turunnya vaiabel X1 (inflasi padi-padian), X2 (inflasi sayur-sayuran), X3 (inflasi kacangkacangan), X4 (inflasi buah-buahan), dan x5 (inflasi bumbu-bumbuan). Sedangkan sisanya sebesar 1,1 persen dijelaskan oleh variabel lain yang tidak dimasukkan dalam model.

Analisis data selanjutnya menunjukkan bahwa variabel yang berpengaruh pada inflasi Kota Manado tahun 2019 adalah inflasi sayuransayuran, inflasi kacang-kacangan dan inflasi buah-buahan dan inflasi bumbu-bumbuan. Sedangkan inflasi padi-padian tidak berpengaruh.

- Inflasi sayur-sayuran berpengaruh pada inflasi Kota Manado dengan tingkat signifikansi 99 persen. Koefisien regresi sebesar 0,051 persen menunjukkan bahwa apabila inflasi sayursayuran bertambah 1 persen maka akan mempengaruhi inflasi Kota Manado 0,051 persen. 
- Inflasi kacang-kacangan berpengaruh pada inflasi Kota Manado dengan tingkat signifikan 99,6 persen. Koefisien regresi sebesar $-0,342$ persen menunjukan bahwa apabila inflasi kacang-kacangan bertambah 1 persen maka akan mempengaruhi inflasi Kota Manado sebesar 0,342 persen.

- Inflasi buah-buahan berpengaruh pada inflasi Kota Manado dengan tingkat signifikan 99,74 persen. Koefisien regresi sebesar 0,080 persen menunjukan bahwa apabila inflasi buah-buahan bertambah 1 persen maka akan mempengaruhi inflasi Kota Manado sebesar 0,080 persen.

- Inflasi bumbu-bumbuan berpengaruh pada inflasi Kota Manado dengan tingkat signifikan 99,37 persen. Koefisien regresi sebesar $-0,025$ persen menunjukan bahwa apabila inflasi bumbubumbuan bertambah 1 persen maka akan mempengaruhi innflasi Kota Manado sebesar 0,025 persen.

\section{KESIMPULAN DAN SARAN}

\section{Kesimpulan}

Inflasi Kota Manado dipengaruhi oleh komoditas pertanian yaitu kelompok sayursayuran, inflasi kacang-kacangan, inflasi buahbuahan dan inflasi bumbu-bumbuan. kelompok padi-padian tidak berpengaruh pada inflasi Kota Manado.

\section{Saran}

1) Pemerintah melakukan stabilisasi harga, pengelolaan permintaan dan pemantauan kelancaran distribusi terutama pada komoditas yang berpengaruh terhadap inflasi Kota Manado.

2) Dibutuhkan peranan pemerintah melalui tim pengawas inflasi daerah untuk mengawasi inflasi Kota Manado.

\section{DAFTAR PUSTAKA}

Badan Pusat Statistik. 2019. Berita Resmi Statistik, Provinsi Sulawesi Utara. Badan Pusat Statistik Provinsi Sulawesi Utara. https://sulut.bps.go.id. 15 Oktober 2019.

Badan Pusat Statistik. 2020. Indeks Harga Konsumen 2019. Badan Pusat Statistik Sulawesi Utara. Manado.

Nahrowi dan H. Usman. 2009. Pendekatan Populer dan Praktis Ekonometrika. Jakarta. Fakultas Ekonomi Universitas Indonesia.

Sujai, Mahpud. 2011. Dampak Kebijakan Fiskal Dalam Upaya Stabilisasi Harga Komoditi Pertanian. http://pse.litbang. deptan.go.id. Ditelusuri tanggal 15 Oktober 2019. 